\title{
Cultural Competency Education in Pharmacy Curricula-Need and Implementation
}

\author{
Isha Patel ${ }^{1 *}$, Thanveer Gadwal ${ }^{2}$, Shameen Shrestha ${ }^{3}$, Shiama Khieri ${ }^{4}$, Mary Kate Miller ${ }^{5}$, Jason W Guy ${ }^{6}$, \\ Jongwha Chang ${ }^{7}$, Mark Johnson ${ }^{8}$
}

\author{
${ }^{1}$ Department of Pharmacy Practice, Administration and Research, Marshall University School of Pharmacy (MUSOP), One John \\ Marshall Drive, Huntington, West Virginia, USA. \\ ${ }^{2}$ Lakeside Pharmacy, Huntersville, North Carolina, USA. \\ ${ }^{3}$ CVS Pharmacy, Great Falls, VA, USA. \\ ${ }^{4}$ Giant Pharmacy, Stephens City, VA, USA. \\ ${ }^{5}$ Department of Pharmacy Practice, Administration and Research, Marshall University School of Pharmacy (MUSOP), One John \\ Marshall Drive, Huntington, West Virginia, USA. \\ ${ }^{6}$ Department of Pharmacy Practice, College of Pharmacy, The University of Findlay, Findlay, Ohio, USA. \\ ${ }^{7}$ Department of Pharmacy Practice and Clinical Sciences, School of Pharmacy, University of Texas at EI Paso, EI Paso, Texas, USA. \\ ${ }^{8}$ Department of Pharmacy Practice, Bernard J. Dunn School of Pharmacy, Shenandoah University, Winchester, Virginia, USA.
}

\begin{abstract}
Cultural competency is the ability to interact effectively with people of different cultures. Development of cultural competency skills among health professions students has been a challenge to integrate into curricula. However, further integration of cultural competency concepts may be needed in the future as some literature has shown that training in this area can lead to benefits in patient outcomes. To date there have been different methodologies used to enhance cultural competency including didactic training, community engagement and experiential models focused on communication. The Substance Abuse and Mental Health Services Administration has also provided a multi-step plan to help in advancing health professionals' skills in the area of cultural competency. In addition, the Accreditation Council for Pharmacy Education has made cultural competency a major standard for pharmacy programs, thus further integration of valuable instructional methods for cultural competency are needed. Other professional organizations have also started to develop tools and resources to help educate individuals in the area of cultural competency. In the future, further integration of cultural competency education will be necessary to comply with accreditation standards and to improve health professionals' skillset, which may in turn result in improved patient outcomes.
\end{abstract}

Key words: Cultural competency, United States, Curriculum, Education, Healthcare.

\section{INTRODUCTION}

As the ethnic groups in the United States continue to diversify, it has become important for healthcare professionals to become culturally competent in order to provide care that is satisfactory and beneficial for patients. Additionally, healthcare professionals must be prepared to deal with sudden and emerging diseases while providing the best care for patients regardless of their origins, languages, cultures and religious beliefs, especially since pharmacists have started accepting more responsibilities within the realm of public health. According to a policy statement by The American Public Health
Association (APHA), moving forward a pharmacist's aim is to contribute to health education, public health advocacy, health promotion as well as disease prevention in hopes of achieving optimal outcomes for the public. ${ }^{1}$ The APhA code of ethics also states that pharmacists should respect personal and cultural differences among patients. ${ }^{1}$ Thus, identifying areas in which pharmacists can improve competency in aspects of culture is important for practicing pharmacists. Cultural competency, can be defined as "the ability to interact effectively with people of different cultures". ${ }^{2}$ This can sound simple,
DOI: 10.5530/ijopp.13.2.16

Address for correspondence: Dr. Isha Patel, Department of Pharmacy Practice, Administration and Research, Marshall University School of Pharmacy (MUSOP), One John Marshall Drive, Huntington-25755, West Virginia, USA.

Phone no: +1-304-696-7349 Email Id: pateli@marshall.edu

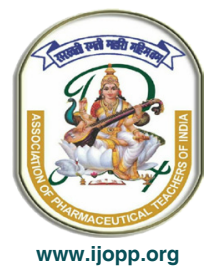


yet this concept becomes challenging to implement. This requires healthcare professionals to understand and listen to patients and therefore be culturally aware of their needs and beliefs. Given that we live in a diverse nation, it is imperative that healthcare professionals understand the cultural beliefs, healthcare needs and attitudes of patients in order to provide effective treatment and service to patients. This paper reviews multiple sources as a way to determine the efficacy of the current educational system for teaching cultural competency in pharmacy school and the necessary improvements to educate student pharmacists for developing cultures in the future.

\section{Need for Cultural Competency Education}

Pharmacists are often very resourceful using their advanced skillset to provide solutions and alternative solutions to help improve patient outcomes, however there are always areas for growth including the area of cultural competence. The Substance Abuse and Mental Health Services Administration (SAMHSA) has proposed a fivestep plan that evaluates the skills needed for professionals to demonstrate cultural competency. ${ }^{3}$ SAMHSA's plan includes assessing needs, building capacity, planning, implementing and evaluating. ${ }^{3}$ To assess needs of the patient, a health care professional must assess how their own perceptions may influence their interaction with others. ${ }^{3}$ To accomplish this, health care professionals must be willing to explore differences and similarities between cultures. ${ }^{3}$ Health care professionals must then build their knowledge regarding other cultures. ${ }^{3}$ Through planning, health care professionals can prepare for new situations or circumstances via open and effective communication. ${ }^{3}$ Through this strategy health care professionals can help implement the plan by encouraging communication and collaboration. ${ }^{3}$ Utilizing this process can aid pharmacists and other health care professionals in providing culturally competent services to patients that will hopefully improve patient outcomes.

There is some evidence that cultural competency training can help improve patient outcomes. Lie et al. conducted a meta-analysis that showed that various forms of culture competency teaching methods helped to improve patient outcomes. ${ }^{4}$ The meta-analysis combined different studies that looked at many forms of teaching pedagogy. For example, studies included the use of experiential modules focused on cultural knowledge and cross-cultural communication. Other designs included a mixture of didactic lectures, group discussions and community engagement. Additionally, other studies have reported that culture competency training helped reduce $\mathrm{A} 1 \mathrm{C}$ and the number of patient no-shows. ${ }^{4}$ Truong et al. found evidence that supported the incorporation of cultural competency training to help improve patient outcomes. ${ }^{4}$ In the meta-analysis, six of eight of the cultural competency interventions resulted in an improvement in patient outcomes. ${ }^{5}$ Truong et al. also described improvements in patient glycemic control in Hispanic populations. Additionally, improved cultural competency has shown positive results in areas of drug addiction and lifestyle modification to improve disease state control. ${ }^{5}$

Improved cultural competence has also been shown to enhance access and utilization of health services. Among the strategies used were providing patients with access to specific patient navigators and health care workers. ${ }^{5}$ Intercultural staff training was also helpful to improve cultural competency and there has been some evidence to suggest that future electronic notifications to health care providers could be helpful to improve cultural competence and thus patient outcomes. ${ }^{5}$ A review by Forsetlund et al. detailed two randomized controlled trials set in inner city Detroit and focused on low income individuals. ${ }^{6}$ Physicians and staff were given electronic reminders to follow-up with patients who should receive a mammography as well as a specific orientation relating to costs of a mammography. ${ }^{6}$ Mammography follow-up rates were higher in the group of patients in which the physicians had an electronic reminder to follow-up. ${ }^{6}$

\section{Implementation of Cultural Competency Education}

Many different strategies have been used to help educate health care professionals on cultural competence. Some strategies used in the past have been to provide workshops or training sessions to healthcare professionals, education for patients, interpreter services and access to patient navigators. ${ }^{5}$ Preliminary evidence has shown that cultural competency trainings significantly increase the cultural competence of healthcare professionals and may even increase patient satisfaction as a result. ${ }^{7}$ Identifying effective exercises to fill gaps in cultural competency is important to educate both current healthcare professionals and future healthcare professionals. ${ }^{7}$

Pharmacy schools are tasked with educating future pharmacists in the area of cultural competence. A study by Okoro et al. shows that students who had exposure to cultural competency instruction through their pharmacy schools were more knowledgeable about cultural health-care disparities and were able to better relate to patients. ${ }^{8}$ As Shaya et al. states, "although health disparities continue to exist as a challenge, health professionals have the improved capacity to work together in addressing and ultimately eliminating health disparities." "Basic knowledge regarding the influence of culture in healthcare 
is necessary for healthcare professional students in order to serve patients of different backgrounds. Didactic and experiential training while in pharmacy school can improve awareness of pharmacists' cultural inadequacies while interacting with patients. ${ }^{10}$ It is important for students to interact with diverse populations during both types of training. ${ }^{10}$ The Accreditation Council for Pharmacy Education (ACPE) is the major accrediting body for Colleges of Pharmacy. As such they produce standards to help guide curricular development. In the 2016 ACPE guidelines, standard 3 states "that a graduate should be able to recognize social determinants of health to diminish disparities and inequities in access to quality care." "11 There are some pharmacy programs in the United States that have already incorporated cultural competency into their core curricula as to help meet these guidelines. Along with ACPE, other national pharmacy organizations, such as the American Pharmacists Association (APhA), the American Society of Health-System Pharmacists (ASHP) and the American College of Clinical Pharmacy (ACCP), have provided guidelines regarding the need to incorporate cultural competence. The American Association of Colleges of Pharmacy (AACP), provides a list of resources that can be used to help educate students regarding cultural competency. ${ }^{12}$ In addition, Halbur and Halbur's APhA learning aid also discusses the need for pharmacists to be able to communicate with their patients and to provide respect for those same patients. ${ }^{13}$ This learning aid is a useful resource when teaching students about cultural competence.

Introducing cultural competency concepts into a course may also be helpful in developing health care professionals in the area of cultural competence, but there is conflicting evidence in the literature. Haack and Phillips found that teaching cultural competency in a pharmacy course helped improve some areas and skills related to cultural competence but the magnitude of this improvement was not thought to be sufficient to elicit true change. ${ }^{14}$ However, in another study pharmacy students were taught a cultural competency course utilizing a teambased learning strategy and these students were found to have enhanced overall cultural competency. ${ }^{15}$ The study noted that the students had increased self-awareness of biases, improved cultural knowledge such as differences in health beliefs among various sociocultural groups, health disparities and health literacy issues and developed skills including health promotion strategies for providing culturally responsive care. ${ }^{15}$ Another study by Muzumdar et al. showed enhanced knowledge and confidence in cultural competence after several class-related activities. ${ }^{16}$ These class-related activities included showing videos of scenarios that pharmacists face that deal with cultural competence in addition to completing written papers on the topic of cultural competence. ${ }^{16}$ Vyas et al. introduced a cultural competency series to help reinforce cultural competency during Introductory Pharmacy Practice Experiences (IPPEs). ${ }^{17}$ This series had different sessions all focused on different topics including religion, socioeconomic status and health disparities. ${ }^{17}$ The series was helpful in improving students' attitudes in regards to cultural competency. ${ }^{17}$

Although more than $90 \%$ of the pharmacy schools in the United States have expressed interest in assimilating cultural competency courses in their schools, less than half of the pharmacy schools have included cultural competency classes. ${ }^{13}$ Due to the lack of cultural competency training in pharmacy school, graduating pharmacists and pharmacy students may not have the cultural awareness needed to properly care for patients. Thus, there is an apparent need for pharmacy schools to provide formal cultural competency training to better prepare pharmacy school graduates for real life patient care scenarios. The Tool for Assessing Cultural Competence Training (TACCT) was developed by the Association of American Medical Colleges (AAMC) to identify areas in the curriculum where cultural competency is taught. A tool similar to this could be useful for Colleges of Pharmacy to identify best practices for teaching cultural competency through the identification of knowledge gaps in current curricula. ${ }^{11}$

Tables 1 and 2 summarize information about cultural competency studies conducted in pharmacy and nonpharmacy schools in the US and across the globe. The studies were chosen based on the type of higher education program and the use of cultural competency education in the program. They reverted to some sort of questionnaire or survey to collect adequate data from their study population. Collectively, the studies demonstrated that cultural competency is an evolving topic, that should be implemented to better prepare health care professionals to treat their patients. Many researchers have used a team-based learning approach, out of class activities and IPPE reinforcement to improve student cultural competency. However, even though the studies showed the benefits of training and education on improving cultural competency among students and health care professionals, the implementation of training or other methods to improve cultural competency has not been robust.

\section{CONCLUSION}

As global diversity continues to increase and evolve, it is important that student pharmacists are prepared adequately for practice in pharmacy. Academicians should 
Table 1: Cultural Competency in Pharmacy Schools in the United States and Other Countries.

\begin{tabular}{|c|c|c|c|c|c|}
\hline $\begin{array}{c}\text { Author and Year } \\
\text { published }\end{array}$ & $\begin{array}{l}\text { Country of } \\
\text { Research }\end{array}$ & Aim of the study & Study design & Methods used & Findings \\
\hline $\begin{array}{l}\text { Popovich et al. } \\
\qquad(2018)^{18}\end{array}$ & $\begin{array}{l}\text { United } \\
\text { States }\end{array}$ & $\begin{array}{l}\text { Determination of } \\
\text { student impressions } \\
\text { of their faculty's } \\
\text { interactions with } \\
\text { students and } \\
\text { patients with diverse } \\
\text { backgrounds }\end{array}$ & $\begin{array}{l}3 \text { student focus } \\
\text { groups were } \\
\text { created and then } \\
\text { transcripts were } \\
\text { analyzed }\end{array}$ & $\begin{array}{l}\text { Qualitative } \\
\text { analysis of } \\
\text { transcripts }\end{array}$ & $\begin{array}{l}\text { Themes identified from qualitative } \\
\text { analysis were faculty awareness } \\
\text { or lack of awareness. First and } \\
\text { second year students focused more } \\
\text { on student interactions, while third } \\
\text { and fourth year students focused } \\
\text { more on their lack of preparation for } \\
\text { future patient encounters. }\end{array}$ \\
\hline $\begin{array}{l}\text { Echeverri et al. } \\
\qquad(2017)^{19}\end{array}$ & $\begin{array}{l}\text { United } \\
\text { States }\end{array}$ & $\begin{array}{l}\text { Determination of } \\
\text { racial dynamics and } \\
\text { need for cultural } \\
\text { competency training } \\
\text { in graduate school } \\
\text { programs }\end{array}$ & $\begin{array}{l}\text { Frequencies, } \\
\text { means and } \\
\text { ANOVAS } \\
\text { determined from } \\
\text { Self-Assessment } \\
\text { of Perceived } \\
\text { Level of Cultural } \\
\text { Competence } \\
\text { (SAPLCC) } \\
\text { questionnaire }\end{array}$ & $\begin{array}{c}\text { SAPLCC } \\
\text { questionnaire }\end{array}$ & $\begin{array}{l}\text { Significant differences were found } \\
\text { in the knowledge, skills, attitudes } \\
\text { and abilities of cultural competence. } \\
\text { There were only slight differences } \\
\text { found in the awareness domain of } \\
\text { cultural competence which were } \\
\text { attributed to the students' attitudes } \\
\text { and personal experiences. This } \\
\text { study found that racial dynamics } \\
\text { and sensitive topics should be } \\
\text { addressed early in the academic } \\
\text { programs. }\end{array}$ \\
\hline Arif et al. $(2017)^{20}$ & $\begin{array}{l}\text { United } \\
\text { States }\end{array}$ & $\begin{array}{l}\text { Determination of the } \\
\text { benefit of simulated } \\
\text { patient case videos } \\
\text { in understanding } \\
\text { cultural } \\
\text { communication in } \\
\text { healthcare }\end{array}$ & $\begin{array}{l}\text { Workshop } \\
\text { discussions with } \\
20 \text { students } \\
\text { about } 3 \text { simulated } \\
\text { pharmacist-patient } \\
\text { case interactions }\end{array}$ & $\begin{array}{l}\text { Pre- and Post- } \\
\text { testing }\end{array}$ & $\begin{array}{l}\text { Using simulated patient case } \\
\text { videos and workshops increased } \\
\text { understanding and comfort with } \\
\text { communicating with people of } \\
\text { different cultures. }\end{array}$ \\
\hline $\begin{array}{l}\text { Ekong et al. } \\
\qquad(2017)^{21}\end{array}$ & $\begin{array}{l}\text { United } \\
\text { States }\end{array}$ & $\begin{array}{l}\text { Determination } \\
\text { of P1 students' } \\
\text { predispositions } \\
\text { to empathy and } \\
\text { intercultural } \\
\text { sensitivity and to } \\
\text { identify potential } \\
\text { needs for skills } \\
\text { training. }\end{array}$ & $\begin{array}{l}\text { Self-reported } \\
\text { perceptions } \\
\text { of empathy, } \\
\text { intercultural } \\
\text { sensitivity and } \\
\text { counseling skills }\end{array}$ & $\begin{array}{l}\text { Cross-sectional } \\
\text { survey with } \\
\text { logistic } \\
\text { regression }\end{array}$ & $\begin{array}{l}\text { There is a need to incorporate } \\
\text { training strategies for } \\
\text { communication skills into the school } \\
\text { curriculum. Areas that need training } \\
\text { are empathy, cultural sensitivity and } \\
\text { motivational interviewing. }\end{array}$ \\
\hline $\begin{array}{l}\text { Katajavuori et al. } \\
\qquad(2017)^{22}\end{array}$ & Finland & $\begin{array}{l}\text { Evaluation of } \\
\text { pharmacy curriculum } \\
\text { for the need for } \\
\text { cultural competency } \\
\text { and up-to-date } \\
\text { learning outcomes. }\end{array}$ & $\begin{array}{l}\text { Curriculum reform } \\
\text { based on relevant } \\
\text { learning outcomes } \\
\text { and cycle degree } \\
\text { programs. }\end{array}$ & $\begin{array}{l}\text { Interviewing } \\
\text { students, } \\
\text { teachers and } \\
\text { pharmacists to } \\
\text { determine the } \\
\text { intended learning } \\
\text { outcomes for a } \\
\text { pharmacy degree } \\
\text { program. }\end{array}$ & $\begin{array}{l}\text { Competence based curriculum } \\
\text { works when the curriculum is } \\
\text { created with the assistance of } \\
\text { students, teachers and experts in } \\
\text { the field. This cooperation results } \\
\text { in new and innovative teaching } \\
\text { practices that benefit all involved. }\end{array}$ \\
\hline $\begin{array}{l}\text { LaRochelle et al. } \\
\qquad(2016)^{23}\end{array}$ & $\begin{array}{l}\text { United } \\
\text { States }\end{array}$ & $\begin{array}{l}\text { Examination of } \\
\text { racial differences } \\
\text { in interprofessional } \\
\text { socialization in } 4^{\text {th }} \\
\text { year pharmacy } \\
\text { students }\end{array}$ & $\begin{array}{l}\text { Two measures } \\
\text { administered } \\
\text { to P4 students } \\
\text { at a historically } \\
\text { black university } \\
\text { to measure } \\
\text { anxiety about } \\
\text { communication } \\
\text { and behavior } \\
\text { towards } \\
\text { interprofessional } \\
\text { collaboration }\end{array}$ & $\begin{array}{c}\text { Personal } \\
\text { Report of } \\
\text { Communication } \\
\text { Apprehension } \\
\text { (PRCA-24) and } \\
\text { Interprofessional } \\
\text { Socialization and } \\
\text { Valuing Scale } \\
\text { (ISVS) }\end{array}$ & $\begin{array}{l}\text { Racial differences need to be } \\
\text { further explored and the curriculum } \\
\text { should promote learning of } \\
\text { communications with different racial } \\
\text { groups. }\end{array}$ \\
\hline
\end{tabular}

Continued... 
Table 1: Cont'd.

\begin{tabular}{|c|c|c|c|c|c|}
\hline $\begin{array}{c}\text { Author and Year } \\
\text { published }\end{array}$ & $\begin{array}{l}\text { Country of } \\
\text { Research }\end{array}$ & Aim of the study & Study design & Methods used & Findings \\
\hline $\begin{array}{l}\text { Crawford et al. } \\
\qquad(2016)^{24}\end{array}$ & $\begin{array}{l}\text { United } \\
\text { States }\end{array}$ & $\begin{array}{l}\text { Examination of self- } \\
\text { perception of serving } \\
\text { culturally diverse } \\
\text { patients at both } \\
\text { beginning and end of } \\
\text { pharmacy school }\end{array}$ & $\begin{array}{c}\text { Surveys } \\
\text { performed on } \\
\text { cohorts made } \\
\text { up of pharmacy } \\
\text { school students in } \\
\text { a particular year } \\
\text { and a follow up } \\
\text { survey with one } \\
\text { cohort }\end{array}$ & $\begin{array}{l}\text { Cross-sectional } \\
\text { survey across } \\
\text { all four years of } \\
\text { pharmacy school, } \\
\text { with a follow- } \\
\text { up longitudinal } \\
\text { survey three } \\
\text { years later }\end{array}$ & $\begin{array}{l}\text { When the curriculum includes } \\
\text { cultural competency, there were } \\
\text { improved perceptions of readiness } \\
\text { to communicate with diverse patient } \\
\text { populations. Further studies should } \\
\text { be performed on program outcomes } \\
\text { when teaching cultural competency. }\end{array}$ \\
\hline $\begin{array}{l}\text { Nash et al. } \\
(2016)^{25}\end{array}$ & Australia & $\begin{array}{c}\text { Determination } \\
\text { of relevance of } \\
\text { National Competency } \\
\text { Standards } \\
\text { Frameworks and } \\
\text { suggest changes } \\
\text { to improve cultural } \\
\text { education for } \\
\text { pharmacy students. }\end{array}$ & $\begin{array}{l}\text { Survey conducted } \\
\text { about National } \\
\text { Competency } \\
\text { Standards } \\
\text { (NCS) and the } \\
\text { respondent's } \\
\text { knowledge of } \\
\text { the standards } \\
\text { of cultural } \\
\text { competency. }\end{array}$ & $\begin{array}{l}\text { Online survey } \\
\text { of pharmacy } \\
\text { students, interns, } \\
\text { pharmacists and } \\
\text { educators }\end{array}$ & $\begin{array}{l}\text { The responses demonstrated that } \\
\text { pharmacy students must have } \\
\text { standards and the issues that many } \\
\text { had with the standards had practical } \\
\text { solutions. Continuing-education } \\
\text { for pharmacists helps solidify the } \\
\text { standards learned in school. }\end{array}$ \\
\hline Bondar $(2015)^{26}$ & $\begin{array}{l}\text { United } \\
\text { States }\end{array}$ & $\begin{array}{l}\text { Exploration of } \\
\text { solutions to cultural } \\
\text { competency training } \\
\text { being majorly } \\
\text { from outside the } \\
\text { curriculum }\end{array}$ & $\begin{array}{l}\text { Survey conducted } \\
\text { on cultural } \\
\text { competency in } \\
\text { Pharmacy school } \\
\text { curriculum }\end{array}$ & $\begin{array}{l}\text { Author completed } \\
\text { survey for } \\
\text { Okoro's study } \\
\text { and discussed } \\
\text { his thoughts for } \\
\text { solutions. }\end{array}$ & $\begin{array}{l}\text { The main solution proposed by } \\
\text { this author was to have more } \\
\text { interactions between pharmacy } \\
\text { schools and other health science } \\
\text { schools and having more patient } \\
\text { interaction. }\end{array}$ \\
\hline $\begin{array}{l}\text { Okoro et al. } \\
(2015)^{8}\end{array}$ & $\begin{array}{l}\text { United } \\
\text { States }\end{array}$ & $\begin{array}{l}\text { Examination of the } \\
\text { level of cultural } \\
\text { competency of P3 } \\
\text { students }\end{array}$ & $\begin{array}{l}\text { Chi-square } \\
\text { tests, ANOVA } \\
\text { and multivariate } \\
\text { regression }\end{array}$ & $\begin{array}{l}\text { Cross-sectional } \\
\text { survey conducted } \\
\text { over } 3 \text { years }\end{array}$ & $\begin{array}{l}\text { Standards need to be established } \\
\text { to determine relevant training } \\
\text { and how to incorporate it into the } \\
\text { curriculum. Current efforts have } \\
\text { shown success. }\end{array}$ \\
\hline $\begin{array}{l}\text { Wilby et al. } \\
(2015)^{27}\end{array}$ & $\begin{array}{l}\text { Qatar and } \\
\text { Canada }\end{array}$ & $\begin{array}{l}\text { Development of } \\
\text { a course-based, } \\
\text { cross-cultural student } \\
\text { interaction between } \\
\text { students at two } \\
\text { different universities. }\end{array}$ & $\begin{array}{l}\text { Assessment } \\
\text { of analytical } \\
\text { content and } \\
\text { communication } \\
\text { skills }\end{array}$ & $\begin{array}{l}\text { Professional } \\
\text { skills simulation } \\
\text { through video- } \\
\text { conferencing } \\
\text { between students } \\
\text { in Qatar and } \\
\text { Canada }\end{array}$ & $\begin{array}{l}\text { This intervention was an effective } \\
\text { way to educate students on cultural } \\
\text { competency. Future education in } \\
\text { cultural competency should focus } \\
\text { on direct contact of students with } \\
\text { culturally sensitive situations. }\end{array}$ \\
\hline $\begin{array}{l}\text { Cooper et al. } \\
(2014)^{28}\end{array}$ & $\begin{array}{l}\text { United } \\
\text { States }\end{array}$ & $\begin{array}{l}\text { Determination of } \\
\text { student's perceptions } \\
\text { of cultural } \\
\text { competency during } \\
\text { Advanced Pharmacy } \\
\text { Practice Experiences } \\
\text { (APPEs) }\end{array}$ & $\begin{array}{l}\text { Assessment } \\
\text { of cultural } \\
\text { competency } \\
\text { perception via a } \\
\text { questionnaire }\end{array}$ & $\begin{array}{l}\text { Questionnaire at } \\
\text { the end of fourth } \\
\text { APPE }\end{array}$ & $\begin{array}{l}\text { Students self-reported high success } \\
\text { with cultural encounters but were } \\
\text { less comfortable in other situations }\end{array}$ \\
\hline $\begin{array}{l}\text { Hutchins et al. } \\
\qquad(2014)^{29}\end{array}$ & $\begin{array}{l}\text { United } \\
\text { States }\end{array}$ & $\begin{array}{l}\text { Exploration of } \\
\text { teaching pharmacy } \\
\text { students as well as } \\
\text { other health science } \\
\text { professionals cultural } \\
\text { competency through } \\
\text { an anthropological } \\
\text { approach }\end{array}$ & $\begin{array}{l}\text { Semester long } \\
\text { course focusing } \\
\text { on Spanish } \\
\text { language, } \\
\text { regional topics } \\
\text { and community } \\
\text { engagement }\end{array}$ & $\begin{array}{l}\text { Finished course } \\
\text { with application } \\
\text { during a } 5 \text { week } \\
\text { trip to Ecuador to } \\
\text { help meet health } \\
\text { needs in the } \\
\text { country. }\end{array}$ & $\begin{array}{l}\text { Combining both language and } \\
\text { anthropological studies provided } \\
\text { a better outcome for cultural } \\
\text { competency development than just } \\
\text { learning language in class alone. }\end{array}$ \\
\hline $\begin{array}{c}\text { Cisneros et al. } \\
\quad(2013)^{30}\end{array}$ & $\begin{array}{l}\text { United } \\
\text { States }\end{array}$ & $\begin{array}{l}\text { Identification } \\
\text { of reasons for } \\
\text { international practice } \\
\text { experiences in } \\
\text { pharmacy curriculum }\end{array}$ & $\begin{array}{l}\text { Sample of } \\
20 \text { pharmacy } \\
\text { schools that have } \\
\text { international } \\
\text { pharmacy } \\
\text { education } \\
\text { programs }\end{array}$ & $\begin{array}{l}\text { Telephone } \\
\text { interviews by } 2 \\
\text { investigators }\end{array}$ & $\begin{array}{l}\text { Even though there are challenges } \\
\text { with international experiences, } \\
\text { the pharmacy schools value the } \\
\text { importance of these educational } \\
\text { experiences as it leads to cultural } \\
\text { competencies. }\end{array}$ \\
\hline
\end{tabular}


Table 1: Cont'd.

\begin{tabular}{|c|c|c|c|c|c|}
\hline $\begin{array}{c}\text { Author and Year } \\
\text { published }\end{array}$ & $\begin{array}{l}\text { Country of } \\
\text { Research }\end{array}$ & Aim of the study & Study design & Methods used & Findings \\
\hline $\begin{array}{l}\text { Sales et al. } \\
(2013)^{31}\end{array}$ & $\begin{array}{l}\text { United } \\
\text { States }\end{array}$ & $\begin{array}{l}\text { Determination } \\
\text { of } 3 \text { educational } \\
\text { interventions and } \\
\text { their effect on cultural } \\
\text { competency }\end{array}$ & $\begin{array}{l}\text { Simulated-patient } \\
\text { activity group, } \\
\text { written case } \\
\text { scenarios group } \\
\text { and formal lecture } \\
\text { group }\end{array}$ & $\begin{array}{l}\text { Pre- and post-test } \\
\text { self-assessment } \\
\text { surveys }\end{array}$ & $\begin{array}{l}\text { Each group experienced positive } \\
\text { changes from pre-test to post-test, } \\
\text { but there was greater change in } \\
\text { the simulated-patient and lecture } \\
\text { groups than in the case scenarios } \\
\text { group. Students may need multiple } \\
\text { classes to truly enhance cultural } \\
\text { competency as } 1 \text { hr intervention } \\
\text { may not be enough. }\end{array}$ \\
\hline $\begin{array}{l}\text { Echeverri et al. } \\
\qquad(2013)^{32}\end{array}$ & $\begin{array}{l}\text { United } \\
\text { States }\end{array}$ & $\begin{array}{l}\text { Assessment } \\
\text { of pharmacy } \\
\text { students and their } \\
\text { perceptions of } \\
\text { cultural competency } \\
\text { in relation to treating } \\
\text { patients of different } \\
\text { races and cultures }\end{array}$ & $\begin{array}{l}\text { Pharmacy } \\
\text { students } \\
\text { completed a } \\
\text { questionnaire } \\
\text { that rated } \\
\text { knowledge and } \\
\text { skills in cultural } \\
\text { competency and } \\
\text { were compared } \\
\text { based on } \\
\text { their race and } \\
\text { backgrounds }\end{array}$ & $\begin{array}{l}\text { Self-Assessment } \\
\text { of Perceived } \\
\text { Level of Cultural } \\
\text { Competency } \\
\text { (SAPLCC) } \\
\text { questionnaire }\end{array}$ & $\begin{array}{l}\text { African American students had } \\
\text { higher level of awareness, White } \\
\text { students reported a significantly } \\
\text { lower level of awareness and Asian } \\
\text { Americans reported a significantly } \\
\text { lower level of skills in dealing with } \\
\text { patients of other cultures. }\end{array}$ \\
\hline $\begin{array}{l}\text { O'Connell et al. } \\
\qquad(2013)^{33}\end{array}$ & $\begin{array}{l}\text { United } \\
\text { States }\end{array}$ & $\begin{array}{l}\text { Exploration of } \\
\text { cultural competency } \\
\text { curriculum in } \\
\text { pharmacy schools to } \\
\text { address development } \\
\text { and innovations that } \\
\text { would lead to more } \\
\text { culturally competent } \\
\text { students. }\end{array}$ & $\begin{array}{l}\text { Reviewed } \\
\text { nursing and } \\
\text { medical school } \\
\text { curriculums that } \\
\text { had great success } \\
\text { and proposed } \\
\text { innovations } \\
\text { for pharmacy } \\
\text { schools. }\end{array}$ & $\begin{array}{l}\text { Preliminary } \\
\text { model of } \\
\text { pharmacy } \\
\text { curriculum } \\
\text { with cultural } \\
\text { competency } \\
\text { objectives were } \\
\text { proposed and } \\
\text { future plans for } \\
\text { pharmacy cultural } \\
\text { education was } \\
\text { proposed. }\end{array}$ & $\begin{array}{l}\text { Pharmacy schools have made } \\
\text { progress in terms of cultural } \\
\text { competency, but there is still } \\
\text { some differences between the } \\
\text { different health professions. } \\
\text { Cultural competency standards } \\
\text { were presented for students, post- } \\
\text { graduates and continuing education } \\
\text { seminars for licensed pharmacists. }\end{array}$ \\
\hline Kearney $(2013)^{34}$ & $\begin{array}{l}\text { United } \\
\text { States }\end{array}$ & $\begin{array}{l}\text { Determination of } \\
\text { the design for a } \\
\text { required service- } \\
\text { learning course for } \\
\text { P1 students and } \\
\text { the relevance of } \\
\text { the class for the } \\
\text { curriculum }\end{array}$ & $\begin{array}{l}\text { All P1 students } \\
\text { completed a } \\
\text { 14-week service- } \\
\text { learning course } \\
\text { with community } \\
\text { organizations }\end{array}$ & $\begin{array}{l}\text { Post-course } \\
\text { survey of } \\
\text { students and } \\
\text { supervisors }\end{array}$ & $\begin{array}{l}\text { The survey showed that the } \\
\text { students had achieved the learning } \\
\text { outcomes for the designed course } \\
\text { and that service-learning was an } \\
\text { adequate way to teach students } \\
\text { relevant pharmacy curriculum. }\end{array}$ \\
\hline $\begin{array}{l}\text { Okoro et al. } \\
(2012)^{35}\end{array}$ & $\begin{array}{l}\text { United } \\
\text { States }\end{array}$ & $\begin{array}{l}\text { Determination of } \\
\text { level of cultural } \\
\text { competency of } \\
\text { P3 students and } \\
\text { if demographics } \\
\text { correlates with their } \\
\text { level of cultural } \\
\text { competency. }\end{array}$ & $\begin{array}{l}\text { Analysis of } \\
\text { demographics } \\
\text { of P3 students } \\
\text { and their levels } \\
\text { of cultural } \\
\text { competency } \\
\text { through a survey }\end{array}$ & $\begin{array}{l}\text { Cross-sectional } \\
\text { survey }\end{array}$ & $\begin{array}{l}\text { From this study it was found that } \\
\text { cultural competency topics may } \\
\text { not be adequately taught in the } \\
\text { pharmacy curriculum and relevant } \\
\text { education is needed. }\end{array}$ \\
\hline $\begin{array}{l}\text { Haack et al. } \\
(2012)^{14}\end{array}$ & $\begin{array}{l}\text { United } \\
\text { States }\end{array}$ & $\begin{array}{l}\text { Incorporation of } \\
\text { cultural competency } \\
\text { in the Pharmacy } \\
\text { Skills and Application } \\
\text { courses and } \\
\text { determination if the } \\
\text { students achieved } \\
\text { an adequate level of } \\
\text { cultural competency. }\end{array}$ & $\begin{array}{l}\text { Assessment of the } \\
\text { different types of } \\
\text { learning provided } \\
\text { to the students }\end{array}$ & $\begin{array}{l}\text { Self-reflection, } \\
\text { lecture, diversity } \\
\text { service-learning, } \\
\text { case studies and } \\
\text { discussions }\end{array}$ & $\begin{array}{l}\text { The course alone was shown to } \\
\text { improve some aspects of cultural } \\
\text { competency, but did not show } \\
\text { change in all areas. Further } \\
\text { instruction is needed. }\end{array}$ \\
\hline
\end{tabular}


Table 1: Cont'd.

\begin{tabular}{|c|c|c|c|c|c|}
\hline $\begin{array}{c}\text { Author and Year } \\
\text { published }\end{array}$ & $\begin{array}{l}\text { Country of } \\
\text { Research }\end{array}$ & Aim of the study & Study design & Methods used & Findings \\
\hline $\begin{array}{l}\text { Hawala-Druy } \\
\text { et al. } \\
(2012)^{36}\end{array}$ & $\begin{array}{l}\text { United } \\
\text { States }\end{array}$ & $\begin{array}{l}\text { Implementation } \\
\text { and creation of } \\
\text { cultural competency } \\
\text { curriculum for } \\
\text { millennial students } \\
\text { to make them more } \\
\text { culturally diverse } \\
\text { professionals }\end{array}$ & $\begin{array}{l}\text { Qualitative and } \\
\text { quantitative study } \\
\text { performed to } \\
\text { measure cultural } \\
\text { competence pre- } \\
\text { intervention and } \\
\text { post-intervention }\end{array}$ & $\begin{array}{l}\text { Inventory for } \\
\text { Assessing } \\
\text { the Process } \\
\text { of Cultural } \\
\text { Competence } \\
\text { Student Version } \\
\text { (IAPCC-SV) }\end{array}$ & $\begin{array}{l}\text { Mean scores increased significantly } \\
\text { post-intervention suggesting that } \\
\text { cultural competency course could } \\
\text { benefit students when applied to a } \\
\text { larger scale throughout a graduate } \\
\text { program or university curriculum. }\end{array}$ \\
\hline $\begin{array}{l}\text { Smith et al. } \\
(2011)^{37}\end{array}$ & $\begin{array}{l}\text { United } \\
\text { States }\end{array}$ & $\begin{array}{c}\text { Exploration of } \\
\text { teaching about } \\
\text { disabled patients and } \\
\text { their unique cultural } \\
\text { identity }\end{array}$ & $\begin{array}{l}\text { Pharmacy } \\
\text { education } \\
\text { highlights cultural } \\
\text { competency, but } \\
\text { interactions with } \\
\text { disabled patients } \\
\text { are not mentioned }\end{array}$ & $\begin{array}{l}\text { Other health } \\
\text { professions have } \\
\text { educational } \\
\text { courses that } \\
\text { discuss treatment } \\
\text { of disabled } \\
\text { patients, but } \\
\text { pharmacy } \\
\text { courses have } \\
\text { little to no } \\
\text { mention of } \\
\text { disabled patients } \\
\text { at all. }\end{array}$ & $\begin{array}{l}\text { After reviewing curriculum from } \\
\text { other health professions, proposed } \\
\text { interventions for pharmacy school } \\
\text { courses to include education on } \\
\text { treatment of disabled patients was } \\
\text { proposed. }\end{array}$ \\
\hline $\begin{array}{c}\text { Mathews et al. } \\
\qquad(2011)^{38}\end{array}$ & $\begin{array}{l}\text { United } \\
\text { States }\end{array}$ & $\begin{array}{l}\text { Implementation } \\
\text { of role-reversal } \\
\text { exercises for P1s to } \\
\text { enhance awareness }\end{array}$ & $\begin{array}{l}\text { Volunteers from } \\
\text { deaf community } \\
\text { helped with role- } \\
\text { reversal exercise }\end{array}$ & $\begin{array}{l}\text { Role-reversal } \\
\text { exercise }\end{array}$ & $\begin{array}{l}\text { This exercise effectively taught } \\
\text { students about the importance of } \\
\text { adequate communication between } \\
\text { pharmacists and their patients. }\end{array}$ \\
\hline
\end{tabular}

$\begin{array}{ccc}\begin{array}{c}\text { VanTyle et al. } \\ (2011)^{39}\end{array} & \begin{array}{c}\text { United } \\ \text { States }\end{array} & \begin{array}{c}\text { Implementation of } \\ \text { Spanish language } \\ \text { and culture in } \\ \text { PharmD curriculum. }\end{array} \\ & & \end{array}$

Muzumdar et al. $(2010)^{16}$

Vyas et al. $(2010)^{17}$

\section{Echeverri et al. $(2010)^{40}$ \\ United States}

United

States

United States

Determination of cultural competency of P2 students

after completing cultural competency curriculum.

Incorporation of cultural competency concepts into IPPEs for pharmacy students
Examination of perceived level of cultural competence of pharmacy students and development within 4 years where students

had to fill a

prescription at a pharmacy with no spoken language.

Five elective courses created including cultural immersion trip and APPE with

Spanish-speaking patients.

\section{Cultural competency curriculum was covered in P2 year.}

6 week course to teach cultural competency concepts for IPPES

CCCQ was administered to each class and self-assessment of cultural competence was conducted.
Students

complete a

major or minor in Spanish

P2 students completed a survey after

finishing cultural competency curriculum.

Pre- and Posttest surveys given to the students.

Presentations and activities during the course were evaluated by an administrator.

Clinical Cultural Competency Questionnaire (CCCQ)
Cultural competency curriculum had a positive effect on the cultural awareness of $\mathrm{P} 2$ students and gave them more confidence to serve culturally diverse patients.

This 6 week course increased the students' cultural competency abilities during IPPEs.

This questionnaire allowed the schools to determine which cultural competency skills needed more training and helped develop a better curriculum to educate students to be more culturally competency. 
Table 1: Cont'd.

\begin{tabular}{|c|c|c|c|c|c|}
\hline $\begin{array}{c}\text { Author and Year } \\
\text { published }\end{array}$ & $\begin{array}{c}\text { Country of } \\
\text { Research }\end{array}$ & Aim of the study & Study design & Methods used & Findings \\
\hline $\begin{array}{c}\text { Nkansah et al. } \\
\text { (2009). }{ }^{41}\end{array}$ & $\begin{array}{l}\text { United } \\
\text { States }\end{array}$ & $\begin{array}{l}\text { Exploration of } \\
\text { the benefits of } \\
\text { diversity and how } \\
\text { administrators and } \\
\text { faculty use it to } \\
\text { develop programs. }\end{array}$ & $\begin{array}{l}\text { Review of } \\
\text { important topics } \\
\text { in discussing } \\
\text { diversity and } \\
\text { how it plays an } \\
\text { important role in } \\
\text { education }\end{array}$ & $\begin{array}{l}\text { Detailed } \\
\text { explanation of } \\
\text { diversity and } \\
\text { how people } \\
\text { are reluctant } \\
\text { to change } \\
\text { educational } \\
\text { practices to } \\
\text { include diversity. }\end{array}$ & $\begin{array}{l}\text { This paper detailed the importance } \\
\text { of incorporating diversity into } \\
\text { educational programs and } \\
\text { curriculums. It explored the attitudes } \\
\text { people have towards including } \\
\text { diversity topics and why adding } \\
\text { diversity to the curriculum can } \\
\text { sometimes be met with resistance. }\end{array}$ \\
\hline $\begin{array}{l}\text { Jungnickel et al. } \\
\qquad(2009)^{42}\end{array}$ & $\begin{array}{l}\text { United } \\
\text { States }\end{array}$ & $\begin{array}{l}\text { Analysis of } \\
\text { literature to provide } \\
\text { recommendations } \\
\text { for the curriculum for } \\
\text { future pharmacists. }\end{array}$ & $\begin{array}{l}\text { Analysis of } \\
\text { the roles of } \\
\text { pharmacists and } \\
\text { what they should } \\
\text { be able to do in } \\
\text { providing care to } \\
\text { culturally diverse } \\
\text { populations }\end{array}$ & $\begin{array}{l}3 \text { functional roles } \\
\text { for pharmacists } \\
\text { with } 5 \text { cross- } \\
\text { cutting abilities }\end{array}$ & $\begin{array}{l}\text { This paper focused on the } \\
\text { importance of curriculum that } \\
\text { included more experiential learning } \\
\text { opportunities and less memorization } \\
\text { of material. The curriculum for } \\
\text { future pharmacists should be } \\
\text { developed in a manner where there } \\
\text { is evidence to support the method } \\
\text { that is being utilized. }\end{array}$ \\
\hline $\begin{array}{l}\text { Poirier et al. } \\
(2009)^{15}\end{array}$ & $\begin{array}{l}\text { United } \\
\text { States }\end{array}$ & $\begin{array}{l}\text { Evaluation and } \\
\text { implementation of } \\
\text { a course on health } \\
\text { promotion and } \\
\text { literacy about cultural } \\
\text { competency }\end{array}$ & $\begin{array}{l}\text { Students were } \\
\text { assessed } \\
\text { on cultural } \\
\text { competency } \\
\text { skills by taking } \\
\text { readiness } \\
\text { assessment tests } \\
\text { (RATs), group } \\
\text { presentations, } \\
\text { portfolio } \\
\text { reflections and } \\
\text { panel discussions. }\end{array}$ & $\begin{array}{l}\text { Pre-course and } \\
\text { post-course } \\
\text { IAPCC-R scores } \\
\text { and portfolio } \\
\text { responses as } \\
\text { well as student } \\
\text { suggestions } \\
\text { for course } \\
\text { enhancements. }\end{array}$ & $\begin{array}{l}\text { This initiative demonstrated } \\
\text { students had increased cultural } \\
\text { competency after completion of the } \\
\text { course and helped better prepare } \\
\text { the students for interactions with } \\
\text { culturally diverse patients. }\end{array}$ \\
\hline $\begin{array}{l}\text { Boyce et al. } \\
(2009)^{43}\end{array}$ & $\begin{array}{l}\text { United } \\
\text { States }\end{array}$ & $\begin{array}{l}\text { Creation of a model } \\
\text { of criteria that must } \\
\text { be completed before } \\
\text { entering a pharmacy } \\
\text { school, which would } \\
\text { help the students } \\
\text { be more successful } \\
\text { during and after } \\
\text { pharmacy school. }\end{array}$ & $\begin{array}{l}\text { The data } \\
\text { collected was } \\
\text { used to create } 2 \\
\text { preprofessional } \\
\text { curricular models } \\
\text { for students } \\
\text { preparing to } \\
\text { enter a doctoral } \\
\text { pharmacy } \\
\text { program. }\end{array}$ & $\begin{array}{l}\text { Evidence-based } \\
\text { approach and } \\
\text { use of ACPE } \\
\text { standards and } \\
\text { guidelines }\end{array}$ & $\begin{array}{l}\text { This study found that the } \\
\text { preprofessional curriculum should } \\
\text { be multi-dimensional, focusing on } \\
\text { what the students need to learn to } \\
\text { be pharmacists in the future and } \\
\text { meet the needs of their patients. } \\
\text { It should be revised from time to } \\
\text { time to make sure the curriculum } \\
\text { stays up-to-date. Pharmacy schools } \\
\text { across the US should also consider } \\
\text { a preprofessional curriculum that is } \\
\text { consistent from school to school. }\end{array}$ \\
\hline Haack $(2008)^{10}$ & $\begin{array}{l}\text { United } \\
\text { States }\end{array}$ & $\begin{array}{l}\text { Development of } \\
\text { learning activities in } \\
\text { the APPE curriculum } \\
\text { to improve cultural } \\
\text { competency }\end{array}$ & $\begin{array}{l}\text { Students } \\
\text { participated in a } \\
\text { rotation where } \\
\text { they counseled } \\
\text { patients at a } \\
\text { Mexican grocery } \\
\text { store and went } \\
\text { to a homeless } \\
\text { shelter to do an } \\
\text { HIVIAIDS clinic }\end{array}$ & $\begin{array}{l}\text { Student } \\
\text { reflections were } \\
\text { logged daily } \\
\text { and they had } \\
\text { to complete a } \\
\text { final evaluation } \\
\text { of the course. } \\
\text { These reflections } \\
\text { showed a positive } \\
\text { progression } \\
\text { towards being } \\
\text { more culturally } \\
\text { competent as the } \\
\text { APPE went on. }\end{array}$ & $\begin{array}{c}\text { Culturally diverse patients allow } \\
\text { APPE students to become culturally } \\
\text { competent pharmacists. More } \\
\text { studies should be performed to } \\
\text { determine how to evaluate learning } \\
\text { tools and assess these outcomes } \\
\text { in APPEs. }\end{array}$ \\
\hline
\end{tabular}

Continued... 
Table 1: Cont'd.

\begin{tabular}{|c|c|c|c|c|c|}
\hline $\begin{array}{c}\text { Author and Year } \\
\text { published }\end{array}$ & $\begin{array}{l}\text { Country of } \\
\text { Research }\end{array}$ & Aim of the study & Study design & Methods used & Findings \\
\hline $\begin{array}{l}\text { Kapol et al. } \\
(2008)^{44}\end{array}$ & Thailand & $\begin{array}{l}\text { Evaluation of the } \\
\text { curriculum on } \\
\text { cultural competency } \\
\text { standards }\end{array}$ & $\begin{array}{l}\text { Course syllabi } \\
\text { were collected } \\
\text { and assessed. } \\
\text { A questionnaire } \\
\text { was developed } \\
\text { from the syllabi } \\
\text { and distributed } \\
\text { to course } \\
\text { coordinators for } \\
\text { evaluation of } \\
\text { standards. }\end{array}$ & $\begin{array}{l}\text { Questionnaire } \\
\text { was completed } \\
\text { by course } \\
\text { coordinators }\end{array}$ & $\begin{array}{l}\text { Thai schools met the competency } \\
\text { standards, but more patient- } \\
\text { oriented material should be } \\
\text { included. }\end{array}$ \\
\hline $\begin{array}{c}\text { Austin and } \\
\text { Ensom }(2008)^{45}\end{array}$ & Canada & $\begin{array}{l}\text { Description of the } \\
\text { educational system } \\
\text { for pharmacists } \\
\text { in Canada and } \\
\text { discussion of } \\
\text { whether a doctoral } \\
\text { degree should be the } \\
\text { standard of practice } \\
\text { for pharmacists }\end{array}$ & $\begin{array}{l}\text { Differences } \\
\text { in practice for } \\
\text { pharmacists } \\
\text { are occurring } \\
\text { in the different } \\
\text { provinces and } \\
\text { the nation as a } \\
\text { whole is reviewing } \\
\text { standards for care } \\
\text { that should be } \\
\text { nationwide since } \\
\text { they have national } \\
\text { healthcare. }\end{array}$ & $\begin{array}{l}\text { Discussion of the } \\
\text { licensure process } \\
\text { in Canada and } \\
\text { the opportunities } \\
\text { pharmacists have } \\
\text { in the country. }\end{array}$ & $\begin{array}{l}\text { Pharmacists are an integral part of } \\
\text { the universal health care system } \\
\text { in Canada and while it may be } \\
\text { difficult to discuss a national } \\
\text { educational system for pharmacists, } \\
\text { it is important to research areas } \\
\text { for improvements across all the } \\
\text { provinces. The core values of the } \\
\text { pharmacists are shared throughout } \\
\text { all the provinces, but research is } \\
\text { important to make sure they are } \\
\text { educated to perform the same level } \\
\text { of care no matter which part of } \\
\text { Canada the patient is in. }\end{array}$ \\
\hline $\begin{array}{l}\text { Assemi et al. } \\
\qquad(2007)^{46}\end{array}$ & $\begin{array}{l}\text { United } \\
\text { States }\end{array}$ & $\begin{array}{l}\text { Development and } \\
\text { evaluation of cultural } \\
\text { competency training } \\
\text { for pharmacy school } \\
\text { educators. }\end{array}$ & $\begin{array}{l}\text { 2-day train the } \\
\text { trainer workshop } \\
\text { provided to } \\
\text { pharmacy faculty }\end{array}$ & $\begin{array}{l}\text { Baseline, post- } \\
\text { training and } 9 \\
\text { month follow-up } \\
\text { assessments } \\
\text { were conducted. } \\
\text { They were } \\
\text { evaluated on } \\
\text { their confidence } \\
\text { to teach cultural } \\
\text { competency. }\end{array}$ & $\begin{array}{l}\text { The train-the-trainer model } \\
\text { increased the faculty's confidence } \\
\text { in teaching cultural competency and } \\
\text { demonstrated a possible teaching } \\
\text { strategy for accreditation standards. }\end{array}$ \\
\hline $\begin{array}{c}\text { Onyoni et al. } \\
\qquad(2007)^{47}\end{array}$ & $\begin{array}{l}\text { United } \\
\text { States and } \\
\text { Canada }\end{array}$ & $\begin{array}{l}\text { Assess content } \\
\text { related to cultural } \\
\text { competency in } \\
\text { the curriculum of } \\
\text { pharmacy schools } \\
\text { in the United States } \\
\text { and Canada. }\end{array}$ & $\begin{array}{l}\text { E-mail } \\
\text { assessment of } \\
\text { both curriculum } \\
\text { committee chairs } \\
\text { and student } \\
\text { leaders. }\end{array}$ & $\begin{array}{l}\text { Respondents } \\
\text { reported cultural } \\
\text { competency in } \\
\text { their mission } \\
\text { statement, } \\
\text { curriculum and } \\
\text { the need for } \\
\text { further courses or } \\
\text { learning activities } \\
\text { about cultural } \\
\text { competency. }\end{array}$ & $\begin{array}{l}\text { Curriculum committee chairs were } \\
\text { able to recognize their school's } \\
\text { individual needs for adding cultural } \\
\text { competency to the curriculum, but } \\
\text { after rechecking with these schools, } \\
\text { not all schools have implemented } \\
\text { those changes. }\end{array}$ \\
\hline $\begin{array}{l}\text { Assemi et al. } \\
(2004)^{48}\end{array}$ & $\begin{array}{l}\text { United } \\
\text { States }\end{array}$ & $\begin{array}{l}\text { Implement and } \\
\text { assess cultural } \\
\text { competency course } \\
\text { designed for } \\
\text { pharmacy students. }\end{array}$ & $\begin{array}{l}\text { 8-hr elective } \\
\text { course for cultural } \\
\text { competency } \\
\text { given to } 4^{\text {th }} \text { year } \\
\text { pharmacy school } \\
\text { students. } 12 \text {-item } \\
\text { survey was given } \\
\text { to the students } \\
\text { to evaluate their } \\
\text { awareness and } \\
\text { knowledge. }\end{array}$ & $\begin{array}{l}\text { Survey was } \\
\text { given before and } \\
\text { after the course } \\
\text { to evaluate } \\
\text { the changes in } \\
\text { the students' } \\
\text { perceptions } \\
\text { about cultural } \\
\text { competency. }\end{array}$ & $\begin{array}{l}\text { This course successfully increased } \\
\text { the students' awareness of diversity } \\
\text { and cultural competence. }\end{array}$ \\
\hline
\end{tabular}


Table 2: Cultural Competency in Non-Pharmacy Schools in the United States and Other Countries.

\begin{tabular}{|c|c|c|c|c|c|}
\hline $\begin{array}{l}\text { Author } \\
\text { and Year } \\
\text { published }\end{array}$ & $\begin{array}{l}\text { Type of } \\
\text { School }\end{array}$ & $\begin{array}{l}\text { Country of } \\
\text { Research }\end{array}$ & Aim of the Study & Methods Used & Findings \\
\hline $\begin{array}{l}\text { Marino et al. } \\
\quad(2018)^{49}\end{array}$ & Dental School & Australia & $\begin{array}{l}\text { Analysis of cultural } \\
\text { content in dental } \\
\text { school curriculum. }\end{array}$ & $\begin{array}{l}\text { Two phases with } \\
\text { interviews of staff and } \\
\text { quantitative review } \\
\text { and assessment of } \\
\text { current curriculum. }\end{array}$ & $\begin{array}{l}\text { Previous studies showed } \\
\text { increased cultural content with } \\
\text { doctoral dental students, but } \\
\text { was lacking in nursing and } \\
\text { bachelor level dental programs. } \\
\text { The nursing and bachelor } \\
\text { level dental programs showed } \\
\text { less time devoted to cultural } \\
\text { competency learning and needs } \\
\text { implementation of the courses } \\
\text { similar to those implemented at } \\
\text { the doctoral level. }\end{array}$ \\
\hline $\begin{array}{l}\text { White et al. } \\
(2018)^{50}\end{array}$ & Medical School & United States & $\begin{array}{l}\text { Evaluation of } \\
\text { observations of } \\
\text { courses designed to } \\
\text { teach about health } \\
\text { disparities based } \\
\text { on race and cultural } \\
\text { factors. }\end{array}$ & $\begin{array}{l}\text { 14-session course on } \\
\text { culture, self-reflection } \\
\text { and medicine }\end{array}$ & $\begin{array}{l}\text { Upon completion of a cultural } \\
\text { competency course, the students } \\
\text { had increased awareness of } \\
\text { cultural issues and felt more } \\
\text { confident in providing care to } \\
\text { patients of different races. }\end{array}$ \\
\hline $\begin{array}{l}\text { Metzl et al. } \\
(2018)^{51}\end{array}$ & Medical School & United States & $\begin{array}{l}\text { Exploration of } \\
\text { the benefits of } \\
\text { the inclusion } \\
\text { of structural } \\
\text { competency training } \\
\text { for undergraduate } \\
\text { pre-health programs }\end{array}$ & $\begin{array}{l}\text { Structural } \\
\text { Foundations of Health } \\
\text { Survey given to } \\
\text { Medicine, Health and } \\
\text { Society students. }\end{array}$ & $\begin{array}{l}\text { These students demonstrated } \\
\text { a higher level of understanding } \\
\text { of health disparities between } \\
\text { patients of different races. These } \\
\text { subjects are stressed on different } \\
\text { standardized tests to get into } \\
\text { graduate programs. }\end{array}$ \\
\hline $\begin{array}{l}\text { Forsyth et al. } \\
\qquad(2017)^{52}\end{array}$ & Dental School & Australia & $\begin{array}{l}\text { Provide baseline } \\
\text { analysis of } \\
\text { Indigenous culture } \\
\text { and identify needs } \\
\text { for increased cultural } \\
\text { competency. }\end{array}$ & $\begin{array}{l}\text { Quantitative analysis } \\
\text { of online survey with } \\
\text { open-ended questions } \\
\text { that were compared } \\
\text { for common } \\
\text { responses. }\end{array}$ & $\begin{array}{l}\text { Some indigenous culture content } \\
\text { exists, but more extensive } \\
\text { research is needed to determine if } \\
\text { the amount of content is sufficient } \\
\text { for dental students to interact with } \\
\text { indigenous people in medical } \\
\text { situations. }\end{array}$ \\
\hline $\begin{array}{l}\text { Kessler et al. } \\
\qquad(2017)^{53}\end{array}$ & Medical School & United States & $\begin{array}{l}\text { Analysis of cultural } \\
\text { competency in } \\
\text { emergency medicine } \\
\text { since } 2002 \text {. }\end{array}$ & $\begin{array}{l}\text { Comprehensive } \\
\text { literature search about } \\
\text { cultural competency in } \\
\text { emergency medicine. }\end{array}$ & $\begin{array}{l}\text { Despite the importance of cultural } \\
\text { competency in all aspects of } \\
\text { medicine, there are few articles } \\
\text { discussing the implementation of } \\
\text { cultural competency education for } \\
\text { emergency medicine. }\end{array}$ \\
\hline $\begin{array}{l}\text { Petty et al. } \\
(2017)^{54}\end{array}$ & Medical School & United States & $\begin{array}{l}\text { Exploration of } \\
\text { the inclusion } \\
\text { of structural } \\
\text { competency training } \\
\text { in undergraduate } \\
\text { pre-health programs. }\end{array}$ & $\begin{array}{l}\text { Structural } \\
\text { Foundations of Health } \\
\text { Survey to evaluate } \\
\text { two groups of } \\
\text { graduating seniors in } \\
\text { pre-health curriculum }\end{array}$ & $\begin{array}{l}\text { Survey results demonstrated } \\
\text { that seniors graduating from an } \\
\text { interdisciplinary program for pre- } \\
\text { health had higher understanding of } \\
\text { cultural competency than pre-med } \\
\text { students. }\end{array}$ \\
\hline $\begin{array}{l}\text { Nicholson } \\
\text { et al. } \\
(2016)^{55}\end{array}$ & Medical School & $\begin{array}{l}\text { Australia and } \\
\text { New Zealand }\end{array}$ & $\begin{array}{l}\text { Assess cultural } \\
\text { competency } \\
\text { education } \\
\text { programs for health } \\
\text { professionals }\end{array}$ & 12-item questionnaire & $\begin{array}{l}\text { There were many variations of } \\
\text { cultural competency education } \\
\text { across all the schools surveyed, } \\
\text { but the common answer was } \\
\text { that lectures were most popular } \\
\text { in teaching cultural competency. } \\
\text { This study helped determine that } \\
\text { a standardized curriculum for } \\
\text { cultural competency education } \\
\text { is needed in these countries to } \\
\text { assure that health professionals all } \\
\text { receive the same type of training. }\end{array}$ \\
\hline
\end{tabular}

Continued... 


\section{Table 2: Cont'd}

\begin{tabular}{|c|c|c|c|}
\hline $\begin{array}{c}\text { Author } \\
\text { and Year } \\
\text { published }\end{array}$ & $\begin{array}{l}\text { Type of } \\
\text { School }\end{array}$ & $\begin{array}{l}\text { Country of } \\
\text { Research }\end{array}$ & Aim of the Study \\
\hline $\begin{array}{l}\text { Gordon et al. } \\
(2016)^{56}\end{array}$ & Medical School & United States & $\begin{array}{l}\text { This study discusses } \\
\text { the disparities found } \\
\text { in the healthcare } \\
\text { system with regards } \\
\text { to the different } \\
\text { racial and ethnic } \\
\text { backgrounds of } \\
\text { patients. }\end{array}$ \\
\hline
\end{tabular}

Smith et al. Podiatric United States

$(2016)^{57} \quad$ Medicine

\section{et al.}

$(2015)^{58}$

$\begin{array}{ccc}\begin{array}{c}\text { Alrqiq et al. } \\ (2015)^{59}\end{array} & \text { Dental School } & \text { United States } \\ & & \\ \begin{array}{c}\text { Hack et al. } \\ (2015)^{60}\end{array} & \begin{array}{c}\text { Nutrition } \\ \text { Scientists }\end{array} & \text { Canada }\end{array}$

Matza et al. Nursing School United States $(2015)^{61}$

Hudson Medical School Canada

and Maa $(2014)^{62}$
Describe which skills nurses need in cultural competency.

\section{Methods Used}

Findings

Assessment of cultural competency program for $3^{\text {rd }}$ year medical students.

Exploration of the benefits of cultural competency education at the college and graduate level.

Evaluation of a midwifery program's approach to treating patients with different cultural backgrounds and the curriculum necessary for discussing racism in the healthcare system.

10 week online cultural competency course with pre- and post-test survey.

There was a treatment and control group.

Multidisciplinary team of librarians, faculty and medical students helped

design a programming series for cultural competency awareness in the healthcare system.

Evaluation of cultural competency curriculum

Assessment of Canadian nutrition students' cultural competency levels and identify areas for improvements

11 item questionnaire that assessed student cultural competency awareness. Pre-

curriculum and postcurriculum test

24-item questionnaire given to $3^{\text {rd }}$ and $4^{\text {th }}$ year undergraduate nutrition classes
Needs assessment on cultural competency skills.

\author{
Exploration of \\ the mandatory \\ Aboriginal \\ community \\ placement for its \\ medical students.
}

Aboriginal placement was implemented to provide cultural competency training in a hands-on learning style.
Additional data needs to be collected, but the feedback received so far shows that implementation of a cultural competency course can lead to better outcomes for patients. The healthcare providers can become more aware of issues they did not know were occurring and can gear their practice towards being culturally competent.

There was a significant increase in attitude and knowledge of cultural competency after completing the 10 week course.

Thirteen events were hosted and this approach proved to be effective for their participants. This team determined that this approach was easily adaptable to any higher education setting and greatly increased awareness for diversity in the healthcare system

Post-curriculum scores were all higher than pre-curriculum scores. Improvements were statistically significant for all subsets except awareness.

The students had the lowest scores in the multicultural knowledge section. This study found that when there were less barriers to learning about other cultures, the students seemed to have a much higher cultural competency score. Taking courses in cultural cuisine also helped increase the knowledge of cultural competency for these students.

Cultural competency needs for school nurses were discussed from the results of the needs assessment test. School nurses need cultural competency training to be able to treat students from different cultural backgrounds.

Cultural immersion has helped medical students learn about the different cultures they may treat as physicians. More research is needed to determine which educational practices are the most effective.

Continued... 


\section{Table 2: Cont'd.}

\begin{tabular}{|c|c|c|c|c|c|}
\hline $\begin{array}{l}\text { Author } \\
\text { and Year } \\
\text { published }\end{array}$ & $\begin{array}{l}\text { Type of } \\
\text { School }\end{array}$ & $\begin{array}{l}\text { Country of } \\
\text { Research }\end{array}$ & Aim of the Study & Methods Used & Findings \\
\hline $\begin{array}{c}\text { Truong et al. } \\
(2014)^{63}\end{array}$ & $\begin{array}{l}\text { Optometry } \\
\text { School }\end{array}$ & $\begin{array}{l}\text { Australia and } \\
\text { New Zealand }\end{array}$ & $\begin{array}{l}\text { Review courses and } \\
\text { how they prepare } \\
\text { students to be } \\
\text { culturally competent } \\
\text { and to determine } \\
\text { demographic } \\
\text { characteristics of the } \\
\text { current students }\end{array}$ & $\begin{array}{l}\text { Curriculum survey and } \\
\text { cultural awareness } \\
\text { study }\end{array}$ & $\begin{array}{l}\text { Previous cultural competency } \\
\text { training in the curriculum has } \\
\text { led to better cultural awareness } \\
\text { and there is opportunity for } \\
\text { improvement in the cultural } \\
\text { competency education. }\end{array}$ \\
\hline $\begin{array}{l}\text { Beck et al. } \\
(2014)^{64}\end{array}$ & $\begin{array}{l}\text { Physician } \\
\text { Assistant }\end{array}$ & United States & $\begin{array}{l}\text { Determination } \\
\text { of longitudinal } \\
\text { effectiveness of } \\
\text { cultural competency } \\
\text { curriculum in } \\
\text { physician assistant } \\
\text { programs. }\end{array}$ & $\begin{array}{l}\text { Students were divided } \\
\text { into } 2 \text { cohorts and } \\
\text { completed a cultural } \\
\text { awareness survey } \\
\text { at the beginning and } \\
\text { at three intervals } \\
\text { throughout their first } \\
\text { year. }\end{array}$ & $\begin{array}{l}\text { Both cohorts showed similar } \\
\text { results that repeated exposure } \\
\text { to cultural competency education } \\
\text { improved cultural awareness } \\
\text { among students. }\end{array}$ \\
\hline $\begin{array}{l}\text { Holyfield } \\
\text { and Miller } \\
(2013)^{65}\end{array}$ & Dental School & United States & $\begin{array}{l}\text { Implementation of a } \\
\text { cultural competency } \\
\text { training for dental } \\
\text { schools across the } \\
\text { United States. }\end{array}$ & $\begin{array}{l}\text { Dental Tool for } \\
\text { Assessing Cultural } \\
\text { Competence Training } \\
\text { (D-TACCT) }\end{array}$ & $\begin{array}{l}\text { Cultural competence for dental } \\
\text { health professionals is necessary } \\
\text { for them to adequately treat their } \\
\text { patients. This survey will help } \\
\text { determine which areas of cultural } \\
\text { competency the curriculum is } \\
\text { lacking in. }\end{array}$ \\
\hline $\begin{array}{l}\text { Delgado } \\
\text { et al. } \\
(2013)^{66}\end{array}$ & $\begin{array}{l}\text { Clinical Staff at } \\
\text { Mayo Clinic }\end{array}$ & United States & $\begin{array}{l}\text { Exploration of the } \\
\text { benefits of a pilot } \\
\text { program to develop } \\
\text { cultural competence. }\end{array}$ & $\begin{array}{l}\text { Pre-class and post- } \\
\text { class assessment of } \\
\text { cultural competence. }\end{array}$ & $\begin{array}{l}\text { After the educational intervention } \\
\text { the clinical staff reported an } \\
\text { increase in cultural awareness, } \\
\text { which would allow them to provide } \\
\text { better care for diverse patients. }\end{array}$ \\
\hline $\begin{array}{l}\text { Sears } \\
(2012)^{67}\end{array}$ & Medical School & United States & $\begin{array}{l}\text { Determination of } \\
\text { curriculum changes } \\
\text { for adequate } \\
\text { cultural competency } \\
\text { education of medical } \\
\text { students }\end{array}$ & $\begin{array}{l}\text { Social locations } \\
\text { and intersectional } \\
\text { framework of } \\
\text { cultural competence } \\
\text { curriculum were } \\
\text { examined. }\end{array}$ & $\begin{array}{l}\text { Curriculum changes for medical } \\
\text { students could result in more } \\
\text { equitable care across different } \\
\text { racial and ethnic groups. }\end{array}$ \\
\hline $\begin{array}{l}\text { Thew et al. } \\
(2012)^{68}\end{array}$ & Medical School & United States & $\begin{array}{l}\text { Exploration of } \\
\text { solutions to medical } \\
\text { students not } \\
\text { adequately being } \\
\text { taught cultural } \\
\text { competence in the } \\
\text { curriculum. }\end{array}$ & $\begin{array}{l}\text { Deaf Strong Hospital } \\
\text { (DSH) program for } \\
\text { establishing cultural } \\
\text { sensitivity in the } \\
\text { first year of medical } \\
\text { school. }\end{array}$ & $\begin{array}{l}\text { DSH program curriculum could } \\
\text { increase cultural sensitivity and } \\
\text { help with cultural training that is } \\
\text { necessary to improve healthcare } \\
\text { treatment for deaf patients. }\end{array}$ \\
\hline $\begin{array}{l}\text { Marino et al. } \\
\qquad(2012)^{69}\end{array}$ & Dental School & Australia & $\begin{array}{l}\text { Exploration of } \\
\text { levels of cultural } \\
\text { competence and } \\
\text { skills in dental } \\
\text { treatment. }\end{array}$ & $\begin{array}{l}\text { 59-item questionnaire } \\
\text { given to dental } \\
\text { students in their } 4^{\text {th }} \\
\text { year, } 5^{\text {th }} \text { year and } \\
\text { graduates of the } \\
\text { program. }\end{array}$ & $\begin{array}{l}\text { These students generally self- } \\
\text { reported a good level of cultural } \\
\text { competency. These issues could } \\
\text { be further explored to improve } \\
\text { quality of care. }\end{array}$ \\
\hline $\begin{array}{l}\text { Ahmed } \\
\text { and Bates } \\
(2012)^{70}\end{array}$ & Medical School & Canada & $\begin{array}{l}\text { Description of } \\
\text { measurements } \\
\text { of physician's } \\
\text { cultural competency } \\
\text { in health care } \\
\text { interactions }\end{array}$ & $\begin{array}{l}\text { Survey of } 682 \\
\text { physicians }\end{array}$ & $\begin{array}{l}\text { First two phases were pilot study, } \\
\text { third phase resulted in five-factor } \\
\text { solution to physicians' level of } \\
\text { cultural competency. }\end{array}$ \\
\hline $\begin{array}{l}\text { Crenshaw } \\
\text { et al. } \\
(2011)^{71}\end{array}$ & Medical School & United States & $\begin{array}{l}\text { Identification of } \\
\text { cultural competency } \\
\text { curriculum } \\
\text { disparities } \\
\text { when treating } \\
\text { cardiovascular } \\
\text { disease. }\end{array}$ & $\begin{array}{l}4 \text { sessions were } \\
\text { conducted for medical } \\
\text { students to prioritize } \\
\text { a list of cultural } \\
\text { competency concepts. }\end{array}$ & $\begin{array}{l}\text { This type of intervention was } \\
\text { found to be an adequate means } \\
\text { of developing educational content } \\
\text { based on the main concepts that } \\
\text { need to be discussed. }\end{array}$ \\
\hline
\end{tabular}




\section{Table 2: Cont'd.}

\begin{tabular}{|c|c|c|c|c|c|}
\hline $\begin{array}{l}\text { Author } \\
\text { and Year } \\
\text { published }\end{array}$ & $\begin{array}{l}\text { Type of } \\
\text { School }\end{array}$ & $\begin{array}{l}\text { Country of } \\
\text { Research }\end{array}$ & Aim of the Study & Methods Used & Findings \\
\hline $\begin{array}{l}\text { Kamaka } \\
\text { et al. } \\
(2011)^{72}\end{array}$ & Medical School & United States & $\begin{array}{l}\text { Native Hawaiians } \\
\text { experience the } \\
\text { most severe } \\
\text { health disparities } \\
\text { in the state. } \\
\text { Determination of } \\
\text { cultural competency } \\
\text { curriculum for } \\
\text { medical students is } \\
\text { needed. }\end{array}$ & $\begin{array}{l}4 \text { focus groups of } \\
\text { Native Hawaiians } \\
\text { recommended training } \\
\text { and curriculum } \\
\text { changes and } \\
\text { recurrent themes } \\
\text { were analyzed. }\end{array}$ & $\begin{array}{l}\text { The five primary themes } \\
\text { and secondary themes were } \\
\text { specifically requested to be } \\
\text { included in the curriculum to } \\
\text { increase cultural competency } \\
\text { when treating Native Hawaiian } \\
\text { patients. }\end{array}$ \\
\hline $\begin{array}{l}\text { Quinn et al. } \\
\qquad(2011)^{73}\end{array}$ & Oncology & United States & $\begin{array}{l}\text { Identification of } \\
\text { communication skills } \\
\text { needed to provide } \\
\text { Hispanic patients } \\
\text { who speak little } \\
\text { to no English with } \\
\text { oncology treatment. }\end{array}$ & $\begin{array}{l}\text { Survey of oncologists } \\
\text { to determine which } \\
\text { aspects they needed } \\
\text { additional training } \\
\text { to be culturally } \\
\text { competent with their } \\
\text { Hispanic patients. } \\
\text { Pre- and post-test } \\
\text { was conducted for } \\
\text { a workshop that } \\
\text { addressed the topics } \\
\text { in the survey. }\end{array}$ & $\begin{array}{l}\text { The post-test results demonstrated } \\
\text { that the workshop resulted in } \\
\text { a positive response from the } \\
\text { oncologists. This study can } \\
\text { be used to help educate other } \\
\text { health providers about racial and } \\
\text { cultural disparities while focusing } \\
\text { on the skills most needed in that } \\
\text { profession. }\end{array}$ \\
\hline $\begin{array}{l}\text { Khanna } \\
\text { et al. } \\
(2009)^{74}\end{array}$ & $\begin{array}{l}\text { Healthcare } \\
\text { Professionals } \\
\text { and } \\
\text { Administrators }\end{array}$ & United States & $\begin{array}{l}\text { Examination of } \\
\text { cultural competency } \\
\text { training program }\end{array}$ & $\begin{array}{l}\text { Post-then-pre self- } \\
\text { reported evaluation }\end{array}$ & $\begin{array}{l}\text { After the training, participants self- } \\
\text { reported a better understanding } \\
\text { of diverse patients and improved } \\
\text { skills in cultural situations. }\end{array}$ \\
\hline $\begin{array}{l}\text { Genao et al. } \\
(2009)^{75}\end{array}$ & Medical School & United States & $\begin{array}{l}\text { Determination of } \\
\text { the impact of formal } \\
\text { education on cultural } \\
\text { competence for } \\
3^{\text {rd }} \text { year medical } \\
\text { students }\end{array}$ & $\begin{array}{l}\text { Pre-course and post- } \\
\text { course } 40 \text { multiple } \\
\text { choice questionnaire } \\
\text { with an intervention } \\
\text { and a control group. }\end{array}$ & $\begin{array}{l}\text { The medical students in the } \\
\text { intervention group had significantly } \\
\text { increased confidence with cultural } \\
\text { competence knowledge in } \\
\text { comparison to the control group. }\end{array}$ \\
\hline $\begin{array}{l}\text { Horton- } \\
\text { Ikard et al. } \\
(2009)^{76}\end{array}$ & $\begin{array}{l}\text { Communication } \\
\text { Disorders }\end{array}$ & United States & $\begin{array}{l}\text { Provide a model } \\
\text { for teaching } \\
\text { multicultural issues } \\
\text { in communication } \\
\text { sciences and } \\
\text { disorders programs. }\end{array}$ & $\begin{array}{l}\text { The authors provide } \\
\text { a tutorial for basic } \\
\text { needs and issues, } \\
\text { then describe a } \\
\text { framework for } \\
\text { teaching these issues. } \\
\text { Finally, they adapt the } \\
\text { framework to create } \\
\text { a model that would } \\
\text { be beneficial for this } \\
\text { program. }\end{array}$ & $\begin{array}{l}\text { This course could provide a } \\
\text { useful skills base to be culturally } \\
\text { competent and across the } \\
\text { American Speech-Language- } \\
\text { Hearing Association's } 9 \text { content } \\
\text { areas. }\end{array}$ \\
\hline $\begin{array}{l}\text { Brennan } \\
\text { and Cotter } \\
(2008)^{77}\end{array}$ & Nursing School & United States & $\begin{array}{l}\text { Identification of } \\
\text { specific needs of } \\
\text { nursing students } \\
\text { regarding cultural } \\
\text { competency and } \\
\text { their abilities to treat } \\
\text { culturally diverse } \\
\text { patients. }\end{array}$ & $\begin{array}{l}\text { 31-item Blueprint for } \\
\text { Integration of Cultural } \\
\text { Competency in the } \\
\text { Curriculum (BICCC) } \\
\text { survey. }\end{array}$ & $\begin{array}{l}\text { This survey provided evidence } \\
\text { for which areas of cultural } \\
\text { competency education are lacking } \\
\text { for nursing school students. }\end{array}$ \\
\hline $\begin{array}{l}\text { Pilcher et al. } \\
\qquad(2008)^{78}\end{array}$ & Dental School & United States & $\begin{array}{l}\text { Development of a } \\
\text { cultural competency } \\
\text { curriculum and how } \\
\text { that would benefit } \\
\text { health professionals. }\end{array}$ & $\begin{array}{l}\text { Pre-test and post-test } \\
\text { regarding cultural } \\
\text { knowledge and self- } \\
\text { awareness. }\end{array}$ & $\begin{array}{l}\text { Post-test results show that the } \\
\text { content discussed may have } \\
\text { increased cultural competency. } \\
\text { Further research is needed } \\
\text { to provide recommendations } \\
\text { on future development of the } \\
\text { curriculum. }\end{array}$ \\
\hline
\end{tabular}

Continued... 
Table 2: Cultural Competency in Non-Pharmacy Schools in the United States and Other Countries.

\begin{tabular}{|c|c|c|c|c|c|}
\hline $\begin{array}{l}\text { Author } \\
\text { and Year } \\
\text { published }\end{array}$ & $\begin{array}{l}\text { Type of } \\
\text { School }\end{array}$ & $\begin{array}{l}\text { Country of } \\
\text { Research }\end{array}$ & Aim of the Study & Methods Used & Findings \\
\hline $\begin{array}{c}\text { Bentley et al. } \\
(2008)^{79}\end{array}$ & Medical School & United Kingdom & $\begin{array}{l}\text { Exploration of } \\
\text { diversity training for } \\
\text { health professionals } \\
\text { in the United } \\
\text { Kingdom. }\end{array}$ & $\begin{array}{l}\text { Questionnaire survey } \\
\text { for all graduate } \\
\text { professional schools } \\
\text { in the United } \\
\text { Kingdom. }\end{array}$ & $\begin{array}{l}\text { This survey showed discrepancies } \\
\text { in cultural competency teaching } \\
\text { practices between different } \\
\text { healthcare professions and in } \\
\text { different regions of the country. } \\
\text { There should be national } \\
\text { guidelines on cultural competency } \\
\text { training for all health professionals } \\
\text { in the United Kingdom. }\end{array}$ \\
\hline $\begin{array}{l}\text { Hewlett et al. } \\
(2007)^{80}\end{array}$ & Dental School & United States & $\begin{array}{l}\text { Review of data } \\
\text { for oral health } \\
\text { disparities among } \\
\text { patients of different } \\
\text { cultures. }\end{array}$ & $\begin{array}{l}\text { Survey data from } \\
2003 \text { American } \\
\text { Dental Education } \\
\text { Association. }\end{array}$ & $\begin{array}{l}\text { This study demonstrates the } \\
\text { need for a cultural competency } \\
\text { curriculum for dental students. }\end{array}$ \\
\hline $\begin{array}{l}\text { Lie et al. } \\
(2006)^{81}\end{array}$ & Medical School & Unites States & $\begin{array}{c}\text { Compare } \\
\text { perceptions of } \\
\text { cultural competency } \\
\text { instruction from } \\
\text { both students and } \\
\text { educators during } \\
\text { the first } 3 \text { years of } \\
\text { medical school }\end{array}$ & $\begin{array}{l}\text { Tool for Assessing } \\
\text { Cultural Competence } \\
\text { Training (TAACT) } \\
\text { where the mean } \\
\text { percentage of "yes" } \\
\text { responses for both } \\
\text { faculty and students } \\
\text { were calculated. }\end{array}$ & $\begin{array}{l}\text { Faculty and students had similar } \\
\text { scores with the TAACT showing } \\
\text { gaps in cultural competency } \\
\text { education and help guide changes } \\
\text { in the curriculum. }\end{array}$ \\
\hline
\end{tabular}

identify effective ways to implement cultural competency into a College of Pharmacy curriculum by building upon previously published research to help provide the best education for students. A further increase in time spent on cultural competency in the curricula can help shape the future of pharmacy and may help improve patient outcomes by providing enhanced awareness to students training to become pharmacists.

\section{ACKNOWLEDGEMENT}

The authors wish to thank Rebecca Falter, Pharm.D from Shenandoah University School of Pharmacy for reviewing this manuscript.

\section{CONFLICT OF INTEREST}

The authors declare none.

\section{ABBREVIATIONS}

APHA: American Public Health Association; SAMHSA: Substance Abuse and Mental Health Services Administration; ACPE: Accreditation Council for Pharmacy Education; APhA: American Pharmacists Association; ASHP: American Society of Health-Systems Pharmacists; ACCP: American College of Clinical Pharmacy; IPPEs: Introductory Pharmacy Practice Experiences; TACCT: Tool for Assessing Cultural Competence Training; AAMC: Association of American Medical Colleges.

\section{SUMMARY}

Cultural competency is the ability to interact effectively with people of different cultures. Development of cultural competency skills among health professions students has been a challenge to integrate into curricula. In the future, further integration of cultural competency education will be necessary to comply with accreditation standards and to improve health professionals' skillset, which may in turn result in improved patient outcomes.

\section{REFERENCES}

1. American Public Health Association. Who We Are [Internet]. Who We Are. 2018 [cited 2019Sep16]. Available from: https://www.apha.org/apha-communities/ member-sections/public-health-education-and-health-promotion/who-we-are

2. Saha S, Beach MC, Cooper LA. Patient Centeredness, Cultural Competence and Healthcare Quality. Journal of the National Medical Association. 2008;100(11):1275-85.

3. Ducker G. Resources on Cultural Competency [Internet]. Substance Abuse and Mental Health Administration. 2019 [cited 2019Sep16]. Available from: https:// www.samhsa.gov/section-223/cultural-competency/resources

4. Lie DA, Lee-Rey E, Gomez A, Bereknyei S, Braddock CH. Does Cultural Competency Training of Health Professionals Improve Patient Outcomes? A Systematic Review and Proposed Algorithm for Future Research. Journal of General Internal Medicine. 2010;26(3):317-25.

5. Truong M, Paradies $\mathrm{Y}$, Priest $\mathrm{N}$. Interventions to improve cultural competency in healthcare: a systematic review of reviews. BMC Health Services Research. 2014Mar;14(1).

6. Forsetlund L, Eike MC, Vist GE. Effect of interventions to improve health care services for ethnic minority populations. Norsk Epidemiologi. 2011Jul;20(1).

7. Govere L, Govere EM. How Effective is Cultural Competence Training of Healthcare Providers on Improving Patient Satisfaction of Minority Groups? A Systematic Review of Literature. Worldviews on Evidence-Based Nursing. 2016;13(6):402-10.

Indian Journal of Pharmacy Practice, Vol 13, Issue 2, Apr-Jun, 2020 
8. Okoro O, Odedina F, Smith WT. Determining the Sufficiency of Cultural Competence Instruction in Pharmacy School Curriculum. American Journal of Pharmaceutical Education. 2015;79(4):50.

9. Shaya FT, Gbarayor CM. The Case for Cultural Competence in Health Professions Education. American Journal of Pharmaceutical Education. 2006;70(6):124.

10. Haack S. Engaging Pharmacy Students with Diverse Patient Populations to Improve Cultural Competence. American Journal of Pharmaceutical Education. 2008;72(5):124

11. Accreditation Council for Pharmacy Education. PharmD Program Accreditation [Internet]. Accreditation Standards and Key Elements for the Professional Program in Pharmacy Leading to the Doctor of Pharmacy Degree. 2019 [cited 2019Sep16]. Available from: https://www.acpe-accredit.org/pharmd-programaccreditation/

12. American Association of Colleges of Pharmacy. Cultural Competence [Internet]. AACP. 2018 [cited 2019Sep16]. Available from: https://www.aacp.org/resource/ cultural-competence

13. Learning Aids: Essentials of Cultural Competence in Pharmacy Practice [Internet]. Home. 2018 [cited 2019Sep16]. Available from: https://www. pharmacist.com/learning-aids-essentials-cultural-competence-pharmacypractice

14. Haack S, Phillips C. Teaching Cultural Competency Through a Pharmacy Skills and Applications Course Series. American Journal of Pharmaceutical Education. 2012;76(2):27.

15. Poirier TI, Butler LM, Devraj R, Gupchup GV, Santanello C, Lynch JC. A cultural competency course for pharmacy students [Internet]. American journal of pharmaceutical education. American Journal of Pharmaceutical Education; 2009 [cited 2019Sep16]. Available from: https://www.ncbi.nlm.nih. gov/pmc/articles/PMC2739064/

16. Muzumdar JM, Holiday-Goodman M, Black C, Powers M. Cultural Competence Knowledge and Confidence After Classroom Activities. American Journal of Pharmaceutical Education. 2010;74(8):150.

17. Vyas D, Caligiuri FJ. Reinforcing Cultural Competency Concepts During Introductory Pharmacy Practice Experiences. American Journal of Pharmaceutical Education. 2010;74(7):129.

18. Popovich NG, Okorie-Awé C, Crawford SY, Balcazar FE, Vellurattil RP, Moore TW, et al. Assessing Students' Impressions of the Cultural Awareness of Pharmacy Faculty and Students. American Journal of Pharmaceutical Education. 2018;82(1):6161.

19. Echeverri M, Dise T. Racial Dynamics and Cultural Competence Training in Medical and Pharmacy Education. Journal of Health Care for the Poor and Underserved. 2017;28(1):266-78.

20. Arif S, Cryder B, Mazan J, Quiñones-Boex A, Cyganska A. Using Patient Case Video Vignettes to Improve Students' Understanding of Cross-cultural Communication [Internet]. American journal of pharmaceutical education. American Journal of Pharmaceutical Education; 2017 [cited 2019 Sep 16]. Available from: https://www.ncbi.nlm.nih.gov/pubmed/28496276

21. Ekong G, Kavookjian J, Hutchison A. Predisposition for Empathy, Intercultural Sensitivity and Intentions for Using Motivational Interviewing in First Year Pharmacy Students. American Journal of Pharmaceutical Education. 2017;81(8):5989.

22. Katajavouri N, Salminen O, Vuorensola K, Huhtala H, Vuorela P, Hirvonen J. Competence-Based Pharmacy Education in the University of Helsinki. American Journal of Pharmacy Education. 2017Jan;5(4):81.

23. Larochelle JM, Karpinski AC. Racial Differences in Communication Apprehension and Interprofessional Socialization in Fourth-Year Doctor of Pharmacy Students. American Journal of Pharmaceutical Education. 2016;80(1):8.

24. Crawford SY, Awé C, Tawk RH, Pickard AS. A Cross Sectional and Longitudinal Study of Pharmacy Student Perceptions of Readiness to Serve Diverse Populations. American Journal of Pharmaceutical Education. 2016;80(4):62.

25. Nash RE, Chalmers L, Stupans I, Brown N. Knowledge, use and perceived relevance of a professions Competency Standards; implications for Pharmacy Education. International Journal of Pharmacy Practice. 2016;24(6):390-402.

26. Bondar A. A New Practitioner's Perspective on Combining Interprofessional and Cultural Competence Instruction in Pharmacy School Curriculum. American Journal of Pharmaceutical Education. 2015;79(10):160.

27. Wilby KJ, Taylor J, Khalifa SI, Jorgenson D. A Course-based Cross-Cultural Interaction among Pharmacy Students in Qatar and Canada. American Journal of Pharmaceutical Education. 2015;79(2):26.
28. Cooper L-A, Vellurattil RP, Quiñones-Boex A. Pharmacy Students' Perceptions of Cultural Competence Encounters During Practice Experiences. American Journal of Pharmaceutical Education. 2014;78(2):31.

29. Hutchins FT, Brown LD, Poulsen KP. An Anthropological Approach to Teaching Health Sciences Students Cultural Competency in a Field School Program. Academic Medicine. 2014;89(2):251-6.

30. Cisneros RM, Jawaid SP, Kendall DA, McPherson CE, Mu K, Weston GS, et al. International practice experiences in pharmacy education [Internet]. American journal of pharmaceutical education. American Journal of Pharmaceutical Education; 2013 [cited 2019Sep16]. Available from: https://www.ncbi.nlm.nih. gov/pubmed/24249850

31. Sales I, Jonkman L, Connor S, Hall D. A Comparison of Educational Interventions to Enhance Cultural Competency in Pharmacy Students. American Journal of Pharmaceutical Education. 2013;77(4):76.

32. Echeverri M, Brookover C, Kennedy K. Assessing Pharmacy Students' SelfPerception of Cultural Competence. Journal of Health Care for the Poor and Underserved. 2013;24(1A):64-92.

33. Oconnell MB, Bittner MRD, Poirier T, Karaoui LR, Echeverri M, et al. Cultural Competency in Health Care and Its Implications for Pharmacy Part 3A: Emphasis on Pharmacy Education, Curriculums and Future Directions. Pharmacotherapy: The Journal of Human Pharmacology and Drug Therapy. 2013Sep;33(12).

34. Kearney KR. Impact of a Service-Learning Course on First-Year Pharmacy Students' Learning Outcomes. American Journal of Pharmaceutical Education. 2013;77(2):34.

35. Okoro ON, Odedina FT, Reams RR, Smith WT. Clinical Cultural Competency and Knowledge of Health Disparities Among Pharmacy Students. American Journal of Pharmaceutical Education. 2012;76(3):40.

36. Hawala-Druy S, Hill MH. Interdisciplinary: Cultural competency and culturally congruent education for millennials in health professions. Nurse Education Today. 2012;32(7):772-8.

37. Smith WT, Roth JJ, Okoro O, Kimberlin C, Odedina FT. Disability in Cultural Competency Pharmacy Education. American Journal of Pharmaceutical Education. 20110ct;75(2):26.

38. Mathews JL, Parkhill AL, Schlehofer DA, Starr MJ, Barnett S. Role-Reversal Exercise with Deaf Strong Hospital to Teach Communication Competency and Cultural Awareness. American Journal of Pharmaceutical Education. 2011Nov;75(3):53.

39. Vantyle WK, Kennedy G, Vance MA, Hancock B. A Spanish Language and Culture Initiative for a Doctor of Pharmacy Curriculum. American Journal of Pharmaceutical Education. 20110ct;75(1):4.

40. Echeverri M, Brookover C, Kennedy K. Nine Constructs of Cultural Competence for Curriculum Development. American Journal of Pharmaceutical Education. 2010;74(10):181.

41. Nkansah NT, Youmans SL, Agness CF, Assemi M. Fostering and Managing Diversity in Schools of Pharmacy. American Journal of Pharmaceutical Education. 2009;73(8):152.

42. Jungnickel PW, Kelley KW, Hammer DP, Haines ST, Marlowe KF. Addressing Competencies for the Future in the Professional Curriculum. American Journal of Pharmaceutical Education. 2009;73(8):156.

43. Boyce EG, Lawson LA. Preprofessional Curriculum in Preparation for Doctor of Pharmacy Educational Programs. American Journal of Pharmaceutical Education. 2009;73(8):155.

44. Kapol N, Maitreemit P, Pongcharoensuk P, Armstrong EP. Evaluation of Curricula Content Based on Thai Pharmacy Competency Standards. American Journal of Pharmaceutical Education. 2008;72(1):09.

45. Austin Z, Ensom MHH. Education of pharmacists in Canada [Internet]. American journal of pharmaceutical education. American Journal of Pharmaceutical Education; 2008 [cited 2019Sep16]. Available from: https://www.ncbi.nlm.nih. gov/pubmed/19325948

46. Assemi M, Mutha S, Hudmon KS. Evaluation of a Train-the-Trainer Program for Cultural Competence. American Journal of Pharmaceutical Education. 2007;71(6):110.

47. Onyoni EM, Ives TJ. Assessing Implementation of Cultural Competency Content in the Curricula of Colleges of Pharmacy in the United States and Canada. American Journal of Pharmaceutical Education. 2007;71(2):24.

48. Assemi M, Cullander C, Hudmon KS. Implementation and Evaluation of Cultural Competency Training for Pharmacy Students. Annals of Pharmacotherapy. 2004;38(5):781-6 
49. Mariño RJ, Ghanim A, Barrow SL, Morgan MV. Cultural competence skills in a dental curriculum: A review. European Journal of Dental Education. 2017Jun;22(1).

50. White AA, Logghe HJ, Goodenough DA, Barnes LL, Hallward A, Allen IM, et al. Self-Awareness and Cultural Identity as an Effort to Reduce Bias in Medicine. Journal of Racial and Ethnic Health Disparities. 2017;5(1):34-49.

51. Metzl JM, Petty J, Olowojoba OV. Using a structural competency framework to teach structural racism in pre-health education. Social Science and Medicine. 2018;199:189-201.

52. Forsyth C, Irving M, Tennant M, Short S, Gilroy J. Indigenous cultural competence: A dental faculty curriculum review. European Journal of Dental Education. 2017;22(3)

53. Kessler R, Coates W, Chanmugam A. Twelve Years Since Importance of CrossCultural Competency Recognized: Where Are We Now? Western Journal of Emergency Medicine. 2017Jan;18(2):223-8.

54. Petty J, Metzl JM, Keeys MR. Developing and Evaluating an Innovative Structural Competency Curriculum for Pre-Health Students. Journal of Medical Humanities. 2017Jan;38(4):459-71.

55. Nicholson SL, Hayes MJ, Taylor JA. Cultural Competency Education in Academic Dental Institutions in Australia and New Zealand: A Survey Study [Internet]. Journal of dental education. U.S. National Library of Medicine; 2016 [cited 2019Sep16]. Available from: https://www.ncbi.nlm.nih.gov/ pubmed/27480708

56. Gordon WM, Mccarter SAU, Myers SJ. Incorporating Antiracism Coursework into a Cultural Competency Curriculum. Journal of Midwifery and Womens Health. 2016;61(6):721-5.

57. Smith KM, Geletta S, Langan T. Assessment of a Cultural Competency Program in Podiatric Medical Education. Journal of the American Podiatric Medical Association. 2016;106(1):68-75.

58. Swanberg SM, Abuelroos D, Dabaja E, Jurva S, Martin K, Mccarron J, et al. Partnership for Diversity: A Multidisciplinary Approach to Nurturing Cultural Competence at an Emerging Medical School. Medical Reference Services Quarterly. 2015Feb;34(4):451-60.

59. Alrqiq HM, Scott TE, Mascarenhas AK. Evaluating a Cultural Competency Curriculum: Changes in Dental Students' Perceived Awareness, Knowledge and Skills [Internet]. Journal of dental education. U.S. National Library of Medicine; 2015 [cited 2019Sep16]. Available from: https://www.ncbi.nlm.nih. gov/pubmed/26329024

60. Hack R, Hekmat S, Ahmadi L. Examining the Cultural Competence of Thirdand Fourth-Year Nutrition Students: A Pilot Study. Canadian Journal of Dietetic Practice and Research. 2015;76(4):178-84.

61. Matza M, Maughan E, Barrows BM. School Nurse Cultural Competence Needs Assessment. NASN School Nurse. 2015;30(6):344-9.

62. Hudson GL, Maar M. Faculty analysis of distributed medical education in Northern Canadian Aboriginal communities [Internet]. Rural and remote health. U.S. National Library of Medicine; 2014 [cited 2019Sep16]. Available from: https://www.ncbi.nlm.nih.gov/pubmed/25277126

63. Truong M, Bentley SA, Napper GA, Guest DJ, Anjou MD. How Australian and New Zealand schools of optometry prepare students for culturally competent practice. Clinical and Experimental Optometry. 2014;97(6):540-9.

64. Beck B, Scheel MH, Oliveira KD, Hopp J. Cultural competency in the physician assistant curriculum in the United States: a longitudinal study with two cohorts. Journal of Educational Evaluation for Health Professions. 2014;11:2.

65. Holyfield LJ, Miller BH. A tool for assessing cultural competence training in dental education [Internet]. Journal of dental education. U.S. National Library of Medicine; 2013 [cited 2019Sep16]. Available from: https://www.ncbi.nlm.nih. gov/pubmed/23929568

66. Delgado DA, Ness S, Ferguson K, Engstrom PL, Gannon TM, Gillett C. Cultural Competence Training for Clinical Staff. Journal of Transcultural Nursing. 2013Jun;24(2):204-13.

67. Sears KP. Improving cultural competence education: the utility of an intersectional framework. Medical Education. 2012;46(6):545-51.
68. Thew D, Smith SR, Chang C, Starr M. The Deaf Strong Hospital Program. Academic Medicine. 2012;87(11):1496-500.

69. Marino R, Morgan M, Hawthorne L, Ismail M. Self-reported cultural skills from dental students and graduates from Melbourne, Australia. European Journal of Dental Education. 2012;17(1).

70. Ahmed R, Bates BR. Development of Scales to Assess Patients' Perception of Physicians' Cultural Competence in Health Care Interactions. Journal of Transcultural Nursing. 2012Mar;23(3):287-96

71. Crenshaw K, Shewchuk RM, Qu H, Staton LJ, Bigby JA, Houston TK, et al. What Should We Include in a Cultural Competence Curriculum? An Emerging Formative Evaluation Process to Foster Curriculum Development. Academic Medicine. 2011;86(3):333-41.

72. Kamaka ML, Paloma DSL, Maskarinec GG. Recommendations for medical training: a Native Hawaiian patient perspective [Internet]. Hawaii medical journal. University Clinical, Education and Research Associate (UCERA); 2011 [cited 2019Sep16]. Available from: https://www.ncbi.nlm.nih.gov/ pubmed/22235153

73. Quinn GP, Jimenez J, Meade CD, Muñoz-Antonia T, Gwede CK, Castro E, et al. Enhancing Oncology Health Care Providers Sensitivity to Cultural Communication to Reduce Cancer Disparities: A Pilot Study. Journal of Cancer Education. 2011Sep;26(2):322-5

74. Khanna SK, Cheyney M, Engle M. Cultural Competency in Health Care: Evaluating the Outcomes of a Cultural Competency Training Among Health Care Professionals. Journal of the National Medical Association. 2009;101(9):886-92.

75. Genao I, Bussey-Jones J, George DMS, Corbie-Smith G. Empowering Students With Cultural Competence Knowledge: Randomized Controlled Trial of a Cultural Competence Curriculum for Third-Year Medical Students. Journal of the National Medical Association. 2009;101(12):1241-6.

76. Horton-Ikard R, Munoz ML, Thomas-Tate S, Keller-Bell Y. Establishing a Pedagogical Framework for the Multicultural Course in Communication Sciences and Disorders. American Journal of Speech-Language Pathology. 2009;18(2):192-206.

77. Brennan AMW, Cotter VT. Student Perceptions of Cultural Competence Content in the Curriculum. Journal of Professional Nursing. 2008;24(3):155-60.

78. Pilcher ES, Charles LT, Lancaster CJ. Development and assessment of a cultural competency curriculum [Internet]. Journal of dental education. U.S. National Library of Medicine; 2008 [cited 2019Sep16]. Available from: https:// www.ncbi.nlm.nih.gov/pubmed/18768444

79. Bentley P, Jovanovic A, Sharma P. Cultural diversity training for UK healthcare professionals: a comprehensive nationwide cross-sectional survey. Clinical Medicine. 2008Jan;8(5):493-7.

80. Hewlett ER, Davidson PL, Nakazono TT, Baumeister SE, Carreon DC, Freed JR. Effect of school environment on dental students' perceptions of cultural competency curricula and preparedness to care for diverse populations [Internet]. Journal of dental education. U.S. National Library of Medicine; 2007 [cited 2019Sep16]. Available from: https://www.ncbi.nlm.nih.gov/ pubmed/17554098

81. Lie D, Boker J, Cleveland E. Using the Tool for Assessing Cultural Competence Training (TACCT) to Measure Faculty and Medical Student Perceptions of Cultural Competence Instruction in the First Three Years of the Curriculum. Academic Medicine. 2006;81(6):557-64. 